\title{
The Role of Prayer in Physical Health (Prayer Therapy)
}

\author{
Sadegh Razagh', Gholam Hossein Alishiri* and Hossein Shamsi Gooshki ${ }^{3}$ \\ 'Department of Islamic Education, Kharazmi University, Tehran, Iran \\ ${ }^{2}$ Chemical Injuries Research Center, System Biology and Poisoning Institute, Baqiyatallah University of Medical Sciences, \\ Tehran, Iran; ghalishiri@gmail.com \\ ${ }^{3}$ Department of Medicine, Quran and Hadith Research Center, Baqiyatallah University of Medical Sciences, Tehran, Iran
}

\begin{abstract}
Health has various dimensions: 1. physical health, 2. mental health, and 3. spiritual health that the spiritual health affects the physical and mental health and it is influenced by them at the same time. Prayer is the highest order of worship is the religion of Islam and can have physical, spiritual and spiritual effects on the individual. The prayer affects the individuals' purity, Wudu ${ }^{1}$ and observance of one's health directly affects one's own health. Its physiological effects, such as bowing, strengthen the abdominal muscles, digestive system, the spine, neck, hands legs and thighs. Prostration is considered as the most important part of prayer in the treatment of lumbar discs, strengthening of the neck and increasing blood flow to the brain, which in turn contributes to the relaxation and reduction of anxiety. In this study, while addressing the principles and states of prayer, they are adjusted with the physicians' recommendations, some of the results of which were that prayer is very effective in spiritual and body health. The results of medical research confirm that prayer can be referred to as the spirit and body exercise. There is a significant relationship between those parts of prayer and its components with more medical effects e.g. purity, the presence of the heart, long prostrations, and night prayer that are focused by the religion. The Quran and narrations refer to the multifaceted nature of prayer and its principles. Each principle is like the rings of a chain that provide the worldly and here after health of the human being.
\end{abstract}

Keywords: Body, Healing, Medicine, Prayer, Purity, Soul

\section{Introduction}

Imam Sadiq (peace is upon him) said: God bless Muhammad and Al-Muhammad, and bless me in my prayer... and heal my disease through them ${ }^{2}$.

Prayer, which is known as the greatest worship in Islam, besides being a great religious duty and having unique spiritual blessings, brings the human being to God and ascend him to the highest heaven. It has extensive material blessings in various spheres of life and individual life.

One of the influential aspects of prayer is the positive effects that this great divine worship has on physical health; as Imam Sadiq asks God to make prayer a means of healing ${ }^{3}$.

Since the main purpose of the prayer is to establish a connection between the earth and the pure world and the ascension of man from the downfall to the highest position, and religious authorities and scholars consider attention to the

\footnotetext{
${ }^{1}$ Islamic procedure for cleansing parts of the body.

${ }^{2}$ Mesbah al-Mutahjad and Silah Al-Mutabad, vol. 1, p. 76 and Bahar al-Anwar (T-Beirut), vol. 83, p. 71.

${ }^{3}$ Mesbah al-Mutahjad and Silah Al-Mutabad, vol. 1, p. 76.
}

spirituality and the hereafter primarily, and the material issues are secondary, the subordinate issues are usually ignored.

Maleki Tabrizi says: "Our Sheikh was a companion of righteous men one of whom was a great man from Hamadan that was a well-educated, persistent youth who served the Sheikh to study jurisprudence. In the days when a group of men came to Sheikh from Hamadan and complained of one of Sheikh's brothers about neglecting some business-related affairs, Sheikh ordered Sayyad to write a letter to his brother. He wrote a letter a brought it to Sheikh and he saw that he blames his brother for mistreating people"4.

Therefore, the material presented in this article is not meant to strengthen the physical and material aspects of prayer and prefer them over the spiritual and after life aspects. One should not consider the material aspects of prayer. Human intention is to be the transcendent purposes of the prayer for which the prayer is set and the material aspects will follow the principle aspect.

Of course, in the original Islamic sources, and consequently in the jurisprudential and ethical books, there are references to the existence of the field of physical health in prayer and have received the attention of respected scholars. It could be a good basis for collaborative interdisciplinary efforts. It could be a

${ }^{*}$ Author for correspondence 
proper context for the interdisciplinary joint efforts of the school of theology and university aimed at clarifying its dimensions.

This research is characterized by two are as:

1. Providing richer religious documentation than religious texts on the issue of physical health in prayer.

2. Providing new aspects of health in prayer that are not evident in other texts.

It is hoped that specialists in related disciplines at the university would establish a movement called «Prayer Therapy» by relying on these religious texts so that more attention is paid to this great worship (prayer, health factory) and a service is provided to the health field in a new way.

\subsection{Prayer and Valuing the Health of the Body}

By carefully observing the words and devotions in the prayer and the ones presented by the religious authorities, one could understand the importance and position of the body's health in the actual context and the religion's attention to this fact. Here are some of those words and devotions:

\subsection{Prayer in Qunut and Demand for Health}

Qunut in prayer is a symbol of the most important demands, in the eyes of the religious authorities. One of the most frequent demands of Qunut is the demand for health. Here are some examples.

\subsection{Seeking Afiat which, According to the Authorities Means "Health"}

The Prophet (peace and blessings of Allaah be upon him), after the blessings of guidance, prayed to the Almighty for health in the Qunut of Vatar prayer (the last Rakat of the night prayer) and said $" \mathrm{O}$ God, guide me in the midst of those who guide them, and bless me health in the midst of them that you give them health" .

Imam Sadeq (AS) said in Qunut of Morning Prayer: "O God, forgive us and forgive sins and have mercy on us and grant us forgiveness and forgive our sins in this world and in the hereafter. You are the almighty" .

\subsection{Prayer for the Health of the Body in Prayer Follow-Ups}

According to the traditions, one of the best opportunities for devotions is after prayer. One of the devotions that have been

\footnotetext{
${ }^{4}$ The Mysteries of Prayer (Malik Tabrizi); p. 104.

${ }^{5}$ Man la Yahzara al-Faghih, Vol 1, p. 487.

${ }^{6}$ Man la Yahzara al-Faghih, Vol 1, p. 400.
}

the focus of the infallibles (AS) was asking for the health of the body examples of which are given below:

\subsection{Prayer for the Health of the Body in Common Follow-Ups}

1. The Prophet of God, after two Rakats of the afternoon Nafilas used to ask God "O God, give me health".

2. Prayer for longevity and full health:

O God ... I seek refuge to you from all diseases ... O God, give me health so that I will never get sick again ... O God, I ask you to help me to leave the world healthy and take me into Paradise safely ${ }^{7}$.

1. A comprehensive prayer for the protection of one's health and all that pertains to man from all the dangers in common follow-ups ${ }^{8}$.

2. For the health of the world and the hereafter, say three times after the prayer.

"My God, I truly ask for forgiveness, health and happiness in this world and in the hereafter"

The above-mentioned cases exist in the follow-ups of all prayers; in addition to the specific follow-ups of each prayer is also concerned with the health of the body:

\subsection{Morning and Maghrib Prayer}

A Prayer for Sight and Health in the Eyes: "Give Me Light and Health in My Body"10.

Another prayer after the Morning Prayer says: "O God, give me the most comfortable and least costly health and make me safe from every evil"11.

\subsection{Devotions for the Health of the Body in the Noon Prayer Follow-Ups}

Health in the body ${ }^{12}$

Moreover, in devotion that came after the noon prayer: $\mathrm{O}$ God, do not abandon any illness in me without healing it ${ }^{13}$.

In another devotion that came after the noon prayer: God bless our prayers and devotions and heal diseases sick with them.

\footnotetext{
${ }^{7}$ Al-Balad al-Amin and al-Dara al-Husain; p. 9.

${ }^{8}$ Al-Masbah (Lelkaf'ami) (p. 23).

${ }^{9}$ Mafatih al-Janan, p. 37.

${ }^{10}$ Al-Kafi (Ta-dar al-Hadith), vol. 4, p. 482.

${ }^{11}$ Al-Balad al-Amin and al-Dara al-Husain; p. 19.

${ }^{12}$ Bihar al-Anwar, vol. 84, p. 65.

${ }^{13}$ Mesbah al-Mutahjad, vol. 1, p. 62.
} 


\subsection{Maghrib Prayer Follow-Ups}

"My God, I ask you to release me from calamities".

According to the aforementioned devotions and many other prayers about the health of the body in prayer and around it:

First: Prayer makes people aware of the importance of maintaining physical health.

Second: prayer is effective in ensuring the health of the human body.

Third: physical pain treatment is not just about medicines, but devotions will be effective in this regard.

\subsection{Body Health in the Light of One of the Basics of Prayer (Purity)}

One of the definitive premises of prayer in the absence of which the prayer is vain and futile is 'purity' and the purification of prayer in both the obligatory and recommended part of it will have profound health effects and undeniable remedy in the field of human body health that a part of it is explained here. Since purity in its specific and broad sense is one of the conditions for prayer, it has various dimensions and includes purity in body, place, clothing and special washing called bath and Wudu, making prayer a foundation for health provision. Naturally, such health conditions can provide the foundation for a healthy life for the body and human life.

The necessity of special washing after relieving ${ }^{14}$, Ghusls such as Jinabat, Heiz and Nafas are not obligatory in jurisprudence but merely for saying prayers ${ }^{15}$ and the Friday Ghusl, which come before Friday prayers, have the same conditions. Wudu with its related principles, such as toothbrushes, rinsing mouth, inhalation, etc., are a complete school of health and well-being, and their observance can make a significant difference to the health of the individual and society.

\subsection{Here is a Brief Explanation}

\subsubsection{Praying and Brushing}

Here are four quotes from the Apostle of God that paying attention to it clarifies the role of mouth health on the body:

Point 1. Brushing is considered as part of Wudu:

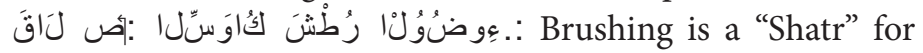
Wudu. The late Majlisi says about the meaning of "Shatr": Shatr either means half; that is, toothbrush in half of purity; or part that is, toothbrush in part of $\mathrm{Wudu}^{16}$.

\footnotetext{
${ }^{14}$ Considering the communities where there are no prayers, washing oneself for relieving is meaningless and sometimes their toilets are waterless. This clarifies the role of prayer in the lifestyle.

${ }^{15}$ TozihAlmasael (Imam Khomeini); p. 83.

${ }^{16}$ Al-Ruda’at al-Motaghin fi Sharh man la Yahzarah Al-Faghih, vol.1, p. 171.
}

Point 2. The importance of brushing during Wudu is as much as the Prophet said: If it was not a burden on my nation, I would command them to brush at any Wudu ${ }^{17}$

Point 3. The Messenger of God said: One prayer, after brushing, is better than 75 prayers without brushing ${ }^{18}$.

Point 4. Brushing at Down and its Health Secrets.

The writer of Wasael al-Shiite has discussed a $\mathrm{Bab}^{19}$ on brushing at dawn and whenever one wakes up, under the heading ${ }^{20}$ and included five narrations in it.

As the science of medicine has proven that the best time to brush is when someone wakes up, the importance of prayer becomes clearer:

For example, there is a narration on the quality of the Prophet's brushing, which is discussed from the medical science perspective.

\subsection{Prophet's Brushing Method}

A hadith of Imam Sadiq says: When the Prophet of Allah (pbuh) said Eshaprayer, he ordered to bring water for his brusing and wudu. They were left above him while they were covered. The Prophet slept for a while and woke up and brushed, performed wudu and said his prayer. Then he said: the Messenger of God is a good example. At the end of the hadith he said: Every time the messenger of God woke up, he would brush.

\subsection{Now Read the Medical Science Perspective on this}

Brush in the morning. Oral saliva at night becomes thicker and more acidic due to inactivity and destroys tooth enamel. Therefore, one should brush his teeth in the morning before eating.

Saliva can be both cleanser and destroyer. When one speaks and the mouth opens, the saliva moves and dilutes, resulting in a cleansing power.

At night, the saliva becomes more acidic due to the mouth being closed and the saliva is stagnant, resulting in softening of the tooth enamel, which is the hardest part of the body. When eating breakfast, which is usually sweet tea at this time, the sweetness penetrates the soft enamel parts of the tooth and causes it to break down ${ }^{21}$.

\footnotetext{
${ }^{17}$ Zekri Al-Shi'a fi Ahkam al-Shari'ah, vol. 2, p. 179.

${ }^{18}$ Bihar al-Anwar, vol. 77, p. 344.

${ }^{19} \mathrm{Bab}$ is a means a set of narratives that are included in a topic, for example five narrations are quoted.

${ }^{20}$ Sheikh HorAmeli, Mohammad bin Hassan, Wassal al-Shiite Qom, First Edition, 1989, vol 2; p. 20

${ }^{21}$ Beytoote website, article "The weapon of war against oral microbes".
} 
Since the human mouth is the center of growth for many microbes, the importance of five times of brushing especially during dawn and after sleep, can reveal the health effects of prayer.

\subsection{Rinsing Mouth and Inhalation}

In addition to brushing, two other issues in are recommended a Wudu and they both play an important role in health. One of these is rinsing mouth, which involves turning the water in and out of the mouth, and the other is "inhaling», which involves pulling water into the nose and exhaling.

It is advisable to first rinse the mouth and then inhale three times.

In fact, rinsing mouth is the complement of brushing and inhalation is a means of cleansing the respiratory tract and the nose.

Since many harmful germs also enter the nose through the air and enter the respiratory tract and body, if they are not washed, they will provide the basis for diseases. Thus, the role of inhalation in health becomes clear.

The treaty of Amir al-Mu'minin said to Muhammad AbiAbiBakr: "Pay attention to the quality of Wudu because it completes your prayer, rinse your mouth, and inhale three times"22.

According to this narrative, the fatwa in the jurisprudence books favored these two purifying acts ${ }^{23}$.

It was even noted that rinsing mouth and inhalation with the right hand (which is typically clean) is preferred ${ }^{24}$.

\subsection{Other Health Effects of Wudu}

1. Effect of Wudu on the safety of the senses: Human science has long classified human senses into five categories (vision, hearing, smell, taste and touch) and these are the five senses that form the broad relationship between man and the world around him.

Facial Cleansing: In verse 9 of the Surah al-Ma'ede it has become obligatory on the Muslims as a divine decree.

In the importance of facial cleansing, it may be enough that the four senses of the five human senses are fully dependent on the face. Water contact, which is the source of purity and life and in addition to the many benefits in terms of neurotransmitters in the human body (which is discussed later), it is important from the point of view of contaminants that may occur in the eye, nose, mouth and facial skin and so on.

\footnotetext{
${ }^{22}$ Al-Amali, (Lelmofid), al-Nas, p. 267.

${ }^{23}$ Al-Mutbar fi Sharh al-Mukhtasar; vol.1, p. 167.

${ }^{24}$ Tahrir al-Ahkam al-Shara'ialaMazhab al-Imamieh (ta-al-hadithi); vol 6, p. 75.
}

2. Health effects of non-drying water:

It is recommended not to dry the Wudu water, as Imam Sadeq says:

Anyone who takes Wudu and dries it has one benefit and if he does not dry he will take 300 benefits".

\subsection{Relationship between Prayer and Electric Charges and Magnetic Field}

The hadiths say not to dry the water of Wudu because of the medical reason that the body spontaneously raises its temperature against a cold that it senses to dry the body, which stimulates the skin to open pores and bring more oxygen to the tissues and the muscles under the skin and brings vitality. The excessive electrical charges that affect the brain waves as a result of magnetic and electrical stimulation around such as power plants, mobile phones, TVs, and hair dryers, which have more serious effects in areas with more nerve stimulation cause more serious dangers and these area are related to Wudu (Head, face, hands, wrists and feet). Water is the best, safest and cheapest way to dispose of these waves and Wudu water transfers the charges around the living body.

\subsection{Prayer and Nutrition Health}

One of the health effects of prayer is that the person praying should take care of his nutrition; for example, Imam Sadeq said about eating and drinking alcoholic things:

"Anyone who drinks alcohol, his prayer is not accepted for forty days. In this narrative it is about drinking, but in another narrative it is generally said: Anyone who gets drunk (whether through drinking, eating or any other way), his prayer is not acceptable to God for forty days"25.

The importance of the matter becomes clear, given the huge detrimental effects that alcoholic drinks have on the health of the human body and soul.

\subsection{Prayer and Discharging Health}

Given that, it is advisable to urinate before any prayer, if it is performed at least three times daily, the urethra is discharged, which in turn leads to bladder and urinary tract health and prevents infection of these sensitive centers.

\subsection{Prayer and Background for the Daily Walking}

Today, few people deny the impact of regular walking on health and most physicians emphasize walking in their health recommendations.

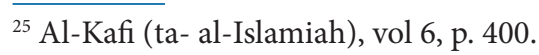


Given the importance of this issue in the health of the body on the one hand, and the fact that the principle of performing prayer is to attend mosques and go to mosques, it is understood that prayer can provide a regular and sacred way for the praying person and actually provide the mobility needed for the body. However, the fact that the principle in prayer is to say it in congregation has a lot of evidence that only one verse and two narratives are brought here for brevity.

But of the verses of the Holy Quran, verse 43 of Surat al-Baqarah states: «And keep up prayer and pay the poor-rate and bow down with those who bow down (43/al-Baqarah).

In the commentaries of the Qur'an, such as the Tabyan commentary by Sheikh al-Tusi, Nemoune, Noor..., they considered this noble verse in prayer to be the reason for the principle of the congregation. That is, although participation in congregational prayer is emphasized, the Muslim man cannot ignore the presence in congregation.

There are many traditions on this subject, but they are generally divided into two groups; one encourages them to attend the congregation and the other denies not participating in the community. One example of each case is brought here:

The first narrative encourages attendance in congregational prayer: Sheikh Sadogh quotes the Prophet of Allah in Thawab al-Amal: Whoever walks to a mosque of God, he receives 10 benefits for every step he takes in return, ten sins are cleansed and ten degrees are added to him. Anyone who watches the congregation's prayers everywhere passes by the bridge of Sarat like a jumper, while his face is as bright as the moon on the fourteenth night and for the care of one night and day for congregation prayer, he receives the honor of a martyr.

\subsection{Narrative Two: Threatening those who Avoid the Congregation Prayer}

Imam Muhammad Baqir was quoted as quoting the Prophet of Allah that: A person that abandons the congregation's prayer reluctantly or unwillingly in the Muslim community, his prayer will not be acceptable ${ }^{26}$. Given these cases and going to mosques three times a day, the place of prayer activity in the community becomes clear.

\subsection{Positive Effects of Bowing on Body Health}

It strengthens the abdominal muscles, protects the digestive tract, prevents indigestion and anorexia, and strengthens the spine, neck, hands, legs and thighs.

It also helps to strengthen the facial muscles of the face, neck, and thighs, thus speeding up blood flow to different parts of the body.

\footnotetext{
${ }^{26}$ Wasael Al-Shi'a, vol 7, p. 299.
}

\subsection{Prostration and its Medical Benefits}

Before discussing the benefits of prostrating from the medical point of view of experts, it should be noted that religiously, "prostration" is the most important part of prayer and in this regard, especially in its prolongation, many traditions have been compiled such as in the hadith of Imam Reza: The closest position of a man to his God is prostrating.

In another hadith, someone says to the Messenger of God: I want to be your companion at the eighth door; His Prophet said: Extend your prostration.

\subsection{However, the View of Medical Professionals in this Regard}

\subsubsection{Long prostration in Medicine}

$\mathrm{He}$ said, "Knee posture is also a condition that increases elasticity of the joints and it is recommended for people with low back pain to spend more time in the posture"27.

According to Easy Medicine Medical Journal, one of the prayer benefits for health is strengthening the neck and treating the disc and spinal cord problems. During prostration, blood flow to the brain increases and strengthens one's understanding and relaxation, as well as happiness, vitality, joy, beauty and freshness.

Moreover, in another study of the effect of prostration on the immune system against harmful waves, reads:

"External magnetic waves damage the DNA of brain cells, and during the day the brain is exposed to external magnetic fields from waves and power plants, and on the other hand, to the Earth's magnetic field, which is extremely harmful to the brain," says Professor Lai. When a person stands in prayer in the Qiblah and during prostration, the magnetic field of the body and the earth coincide and, like a conductor, discharge electrical matter from head to ground he continues $^{28}$.

Other Results on Prostration are as follows:

As the human axis decreases longer, the amount of exposure to electromagnetic radiation reduces. During prostration, both the longitudinal axis of the human body and the subsequent impact of electricity are reduced, and then the discharge is carried out by contacting the forehead with the ground. However, during the prostration, because the other parts of the body are connected to the earth, the discharge procedure is easy and human beings are saved from mental, physical and even cancer diseases ${ }^{29}$.

\footnotetext{
${ }^{27}$ Site of Medical Journal, Mohammad Khassavand, Binghamton University of America.

${ }^{28}$ Ibid

${ }^{29}$ Mikneh website, the medical effects of prayer
} 


\subsection{Night Prayer and Body Health}

According to research by Egyptian physician Madhat al-Shami, melatonin levels at night and at noon need no medication.... Most emergency heart disease is five to nine in the morning that melatonin secretion is maximized by waking up in the Morning Prayer and Prevents cardiac complications. Increased melatonin levels by waking up for Morning Prayer counteract the effects of free radicals and prevent premature aging by Alzheimer and Parkinson's.

Increased melatonin hormones in night prayer maintain brain cells and the power of thought and increase the ability of white blood cells in the body's defense mechanism against cholesterol and vascular stenosis. Increased melatonin levels in night and morning prayers protect the cells of the eye and prevent the lens or capsule from becoming opaque, as Imam Sadeq (AS) said: Night prayers increase human vision.

Increased melatonin hormone in night and morning prayers increases secretion of endorphins and enkephalins that regulate sleep and relaxation ${ }^{30}$.

One of the benefits of prayer for health is a longer life span. Studies have shown that increasing hormones such as cortisol, melatonin, and dopamine in waking up at night and at dawn will lead to health and longevity ${ }^{31}$.

\section{Conclusions}

Based on the previous discussions it is concluded

1. Prayer is a unique truth in the health of the soul and body.

2. There is a significant relationship between those parts of prayer and its components and medical effects such as purity, the presence of heart, long prostrations and night prayers emphasized religiously.

\section{References}

1. Tusi, Mohammed bin al-Hassan, Mesbah al-Mutahjad, Silah Al-Mutabad. Beirut. First Edition, 1991.

2. Isfahani, Hussein ibn Muhammad Ragheb, Mufradat al-Faz al-Qur'an, in a volume, Dar al-Alam-Eldar al-Shami, LebanonSyria, $1^{\text {st }}$ edition, 1992.

3. Esfahani, Second Majlisi, Mohammad Bagher bin Mohammad Taghi, Bihar al-Anwar, vol.33, Institute of Al-Taiba and Al-Nashar, Beirut-Lebanon, $1^{\text {st }}$ edition, 1990.

4. Ameli, Martyr I, Mohammad IbnMacki, Zakari al-Shi'i fi Hikam al-Shariah, 4 vols., Al-Bait Institute of Islam, Qom-Iran, $1^{\text {st }}$ edition, 1999.

\footnotetext{
${ }^{30}$ Site owned by AndishehPardazan Company.

${ }^{31}$ AsanTeb Site, Article: The Benefits of Prayer for Body Health.
}

5. Khomeini, Sayyid Ruhollah Mousavi, Tozih Almasael (Imam Khomeini), in a volume, first edition, 2006.

6. Esfahani, First Majlisi, Mohammad Taghi, Al-Ruda'at al-Motaghin fi Sharh man la Yahzarah Al-Faghih, Vol 13, Kushanbour Islamic Cultural Institute, Qom-Iran, Second, 1986.

7. Qomi, Saduq, Mohammad ibn Ali ibnBaboieh, Thawab al-Amal and Eghab al-Amal, in a volume, Dar al-Sharif al-RaziLaleshar, Qom - Iran, Second, 1986.

8. Ameli, Hor, Mohammad bin Hassan, Wasael al-Shiite, 30 vols., Al-Albit Institute, Qom - Iran, 1 1989.

9. Heli, Allameh, Hassan ibn Yusuf bin MotaharAsadi, Tahrir al-Ahkam al-Shara'ialaMazhab al-Imamieh (ta-al-hadithi); vol 6, Imam Sadiq Institute, Qom - Iran, 1' 2000.

10. Ameli, Hor, Mohammad bin Hassan, Wasael al-Shiite, 30 vols., Al-Albit Institute, Qom - Iran, $1^{\text {st }}, 1989$.

11. Tabarsi, HasanibnFazl, Makaram al-Akhlaq - Qom, published: Fourth, 1981.

12. Maghrebi, Abu Hanifa, Naaman bin Mohammad Tamimi, Da’aem al-Islam, Vol 2, -Albit Institute, Qom - Iran, Second, 1965.

13. Heli, Mohaqiq, Najm al-Din, Ja'faribn Hassan, Al-Mutabar fi Sharh al-Muqtasr, Vol 2, Sayyid al-Shohada Institute, Qom - Iran, $1^{\text {st }}, 1987$

14. Barghi, Abu Ja'far, Ahmad ibn Muhammad ibn Khalid, alMahasin (LelBarghi), Vol2, Dar al-KotobIslami, Qom - Iran, Second, 1951.

15. Esfahani, First Majlisi, Mohammad Taghi, Al-Ruda’at al-Motaghin fi Sharh man la Yahzarah Al-Faghih, Vol 13, Kushanbour Islamic Cultural Institute, Qom-Iran, Second, 1986.

16. Tusi, Abu Ja'far, Muhammad bin Hassan, Mesbah al-Mutahjad, 2 vols., Institute of Shiite Jurisprudence, Beirut - Lebanon, $1^{\text {st }}, 1991$.

17. Esfahani, Second Majlisi, Mohammad Bagher bin Mohammad Taghi, Translated by: Alami, Ala’ad, Zad al-Ma’ad - Mafatih al-Janan, in a volume, Beirut - Lebanon, $1^{\text {st }}, 2003$.

18. Tabrizi, Maleki Mirza Javad. Translated by Rajabzadeh, Reza, I sarar al-Sala’i (Maleki Tabrizi), in a volume, Payam-e Azadi Publications, Tehran-Iran, Fourth, 2000.

19. Mofid, Muhammad ibn Muhammad, al-Amali (Lalmfid) - Qom, First Edition, 1993.

20. Esfahani, Second Majlisi, Mohammad Bagher bin Mohammad Taghi, Bihar al-Anwar, vol.33, Institute of Al-Taiba and Al-Nashar, Beirut-Lebanon, $1^{\text {st }}$ edition, 1990.

21. Qomi, Sheikh Abbas, Mafatih Al-Janan. Center for Scientific Publications, Sixth Edition, 1988.

22. Ameli, Kaf'ami, Ibrahim bin Ali, Al-Balad al-Amin and al-Dara al-Husain, in a volume, Aalmi Institute, Beirut - Lebanon, $1^{\text {st }}$, 1998.

23. Koleini, Abu Jafar, Mohammed bin Ya’qub, Al-Kafi (T-Dar al-Hadith), 15 volumes, Dar al-Hadith Lalbaba'i and Al-Nashar, Qom - Iran, $1^{\text {st }}, 2009$.

24. Ameli, Kaf'ami, Ibrahim bin Ali, al-Masbah (lelKaf'ami), in a volume, Dar al-Razi (Zahedi), Qom-Iran, II, 1985.

25. Khomeini, TozihAlmasael, Reference Book Software, Version 407, Database Version 102. 
26. Qomi, Saduq, Mohammad ibn Ali ibnBaboieh, Man la Yahzara al-Faghih, Vol 4, Qom Seminary of Islamic Publications, Qom Iran, Second, 1993.

27. Qomi, Saduq, Mohammad ibn Ali ibnBaboieh, Translated by Ghaffari, Ali Akbar, Mohammed, Man la Yahzara al-Faghih,
Vol 6, Sadough Publishing, Dilami, Hassan Ibn Mohammad, AlamuddinFayyat Al-Mu'minin, Qom, $1^{\text {st }}$ edition, 1988 Iran, First, 1989. 